DOI : $10.14746 /$ ps.2019.1.8

John Paul II Catholic University of Lublin

https://orcid.org/0000-0002-1323-5912

\title{
Central Europe and NATO Transformation 2014-2018
}

The 1998 socio-political transformations in Central European states have delineated a clear direction for shaping a new security area. Nearly all states of the region decided to embark upon actions needed to allow them to integrate relatively quickly with EuroAtlantic institutions. The key issue was to ensure security of the state, which made the decision to join the North Atlantic Alliance (NATO) an obvious one (Smith, Graham, 2018). The first three states to achieve this objective, already in 1999, were the Czech Republic, Hungary and Poland. Every couple of years they were joined by another state from the region. There is no doubt that gaining NATO membership was a considerable success for the ex-Soviet Bloc and Warsaw Pact states. All this happened within ten years of the collapse of the Cold-War order (1989), eight years after the dissolution of the Warsaw Pact (1991) and seven years after the Soviet Army left the territory of Poland (1993). Each of the Central European states had successfully cooperated with NATO security systems even before they gained their membership. Their involvement has increased ever since they became full members of the Alliance. Their soldiers have actively participated in stabilisation and peacekeeping missions and undergone regular training. The cooperation has been carried out at multiple levels. Different Alliance institutions are located in some of these states. One of the outcomes of the involvement and importance of the region for NATO security policy was also the decision to hold subsequent summits in new member states of the Alliance: in Prague in 2002, in Riga in 2006 and in Bucharest in 2008.

The objective of the present text is to outline some priorities in the area of the Central European security in relation to NATO membership. The paper will point to the key decisions taken with respect to the whole region in the years 2014-2018, in accordance with the arrangements of the summits in Newport (2014), Warsaw (2016) and Brussels (2018). Due to new developments in the area of security, expectations related to these events appeared to be exceedingly relevant, particularly for the Central European states. The decisions reached during the summits can be viewed as important and satisfactory.

The work attempts to answer three research questions. 1. On what is the Central European community of interest based, in the context of NATO? 2. How are the basic NATO values implemented, especially those concerning coherence and decisiveness? 3. What were the dynamics of decisions and actions related to the proceedings of the last three NATO summits? It is posited here that the decisions taken during the NATO summits in question were, to a large extent, an outcome of a great determination and effectiveness of the diplomacy of Central European states, especially of Poland. 
When it comes to methodology, the paper predominantly makes use of text analysis and case study methods. ${ }^{1}$

\section{A COMMUNITY OF INTREST IN CENTRAL EUROPE}

Central European states are playing an ever increasing role in NATO. One can no longer speak of "second-class" membership or "new" member status. It has been 20 years since Czech Republic, Hungary and Poland joined the Alliance. All successive NATO summits constituted considerable opportunity for the states of this region to manifest their security priorities. It primarily concerned confirming the readiness on the part of the states to fully participate in NATO operations but it also pertained to securing their interests, particularly with respect to the events in Ukraine and an increased activity on the part of Russia (i.a. as regards an increase in the armament expenditure and operational involvement in the so-called close neighbourhood) and a surge in asymmetrical threats around the world (Sydoruk, Tyshchenko, 2018). One of the objectives in this area is to strengthen the actual presence of NATO in Central Europe (including Eastern Europe). It should not be regarded as a confrontation with any state, including Russia, but ought to stem from real events taking place on geopolitical stage. The meeting of nine leaders and four representatives of the states of this region held on November 4th, 2015 in Bucharest is a good example of an actual manifestation of the objectives of Central European states. ${ }^{2}$ The initiative launched by Andrzej Duda, the president of Poland, was met with considerable interest. During the meeting, all participating states managed to delineate their united stance as concerns the future of NATO, also with respect to the Warsaw summit. For a strong, unanimous stance as regards the subjective participation in the implementation of NATO security policy and securing those states' interests is the only way for them to be heard. It is only by means of cooperation that they stand a chance of being taken seriously and gaining a strong position which is warranted by their membership in the Alliance.

The migrant crisis exposed the weakness of actions undertaken by the EU. Therefore, the so-called "Southern Flank" issue has also become a major challenge for NATO (Kř̌̌ž, Fridrichová, 2015). Mass movements of population carry a potential threat of allowing individuals implicated in terrorist actions to cross borders along with other migrant people. The Syrian Civil War, the brutality of the so-called "Islamic State" (ISIS) make the need to launch multi-faceted actions aimed at the strengthening of the Alliance and all its members apparent. The lack of understanding of the attitude of Central European states, especially V4, as regards their opposition towards imposition of decisions, to mention only the issue of allocating migrants in these states, brings the need to sustain a constructive dialogue and negotiations on the EU forum to the fore. The effective handling of the migrant crisis is not related to their relocation but rather

${ }^{1}$ The author is very grateful to the anonymous reviewers and editors for comments and help to finalize the manuscript.

2 The author adopts a broader view on Central Europe and considers it to cover the region encompassing all the states which created the so-called Bucharest Nine project, along with four Balkan states. All thirteen countries are NATO member states. 
to eradicating its causes - terrorist actions whose roots go back mainly to Syria. Making the external borders secure within the Schengen system cannot be viewed as aimed against war refugees. It stems from respecting the law binding in the EU. Actions undertaken in this area, for instance by Hungary, need to gain support and appreciation of the EU rather than be questioned within the organisation. The "Open Door" Policy preferred by Germany has clearly not worked out. European societies have got a completely different opinion on the so-called political elites. This may lead to a radicalisation of social attitudes in Europe itself, which may also contribute to an increase in internal problems. The time has come to revise wayward decisions which are nowadays (perhaps unwittingly) associated with Chancellor Angela Merkel. Central Europe is an inseparable and important part of the EU. The region wants to be treated in accordance with its subject status, and is actively involved in integration processes. It is difficult to verify the hypothesis concerning leaving the EU by one of these states. One cannot agree with the claim of Central European Euroscepticism. All opinion poles clearly point to a considerable support for the EU membership within these states. In Poland, over $70 \%$ of the population is in favour of the membership (CBOS polls). However, a clear and unequivocal manifestation of one's interests, including those in the area of security, should not come as a surprise. A realistic analysis of the possibilities of shaping Euro-Atlantic security and its effectiveness has to acknowledge the superior role of NATO in these activities. The EU should rather remain a "soft power" concentrated on the implementation of economic cooperation and refrain from its activity as far as duplicating the actions of NATO is concerned. It mainly pertains to some dubious theories related to the creation of an alternative to NATO security policy within the EU, based for instance on a joint European army. Such ideas could result in a weakening of the Euro-Atlantic ties rather than improve European security (Franke, 2018).

\section{The decisiveness of NATO}

The most essential objective in the area of Central European security interests is, undoubtedly, the attainment of sufficiently high decisiveness level. NATO needs to constantly confirm its capacity to take actual actions in each of the four basic areas. These have been repeatedly emphasised, especially in Central Europe (for instance in a speech given by Andrzej Duda, the President of the Republic of Poland) and are closely correlated.

1) active defence of the Alliance territory and deterrence of prospective aggressors;

2) peaceful detente stemming from a departure from the new arms race temptation;

3) combatting new threats, among others in cyberspace, illegal migrations, destabilisation of areas directly neighbouring with the Euro-Atlantic area, hybrid threats, especially those involving terrorism;

4) the capacity to activate funding and modernisation of defence policy.

When approached from this perspective, the most important issue appears to be the ability to draw the correct conclusions as concerns the changing geopolitical reality of the modern world, with a clear view to achieve integration successes in the light of security and defence of NATO member states. The time devoted to debates and con- 
versations is an inherent part of any political alliance. Decisions are, not infrequently, only reached after heated disputes. One cannot, however, be content with declarations. Nowadays, the complex global geopolitical reality requires of states to move from words to deeds, to actual decisions which take into account the interests of NATO as a whole but also those of its individual member states, those who need the most support. This is especially true for Central European states. The main reason for that is Russian radicalisation in terms of its political objectives (those of President Vladimir Putin), its confrontational activities, particularly the repeated provocations including the use of, among others, air forces. It is impossible not to mention a relatively passive reaction to these events on the part of the Alliance. That is not to say that armed forces should have been deployed but a far more active, univocal demonstration of its opposition towards those provocations would have be expected. History has clearly shown that increasing submission does not result in a drop but rather in a surge of activities aimed against sovereignty of states and nations. NATO has at its disposal powerful defensive potential and thus its decisions may (or rather must) result in settling international relations in a rational manner. The world does not have the time to experiment when it comes to security (Nünlist, Zapfe, 2014).

Problems in this respect were often clearly visible during the three NATO summits analysed here. Decisions reached during those summits did not always respond to the actual needs, concerning particular events taking place in the surrounding geopolitical reality, and at times they were postponed.

\section{The increased presence of NATO}

The escalation of threat primarily related to Russia's activities requires of NATO to confirm the permanent presence of its armed forces in Central European states, including Poland. Certainly, this is not a short-term goal. The first step in that direction could be a rotational presence of allied forces and a deployment of NATO defence infrastructure (armament). Not all Central European states fully agree on that point, nor do they have a common stance as regards that issue. Nevertheless, a reinforcement of active military presence in the region seems necessary. It should be based on the basic NATO operational objective, i.e. defence and deterrence. The decisions taken in Poland seem vital in this respect. The acceleration and activity in this area appear to be a way of sending a positive and audible signal aimed at the Alliance. It is important to notice that Poland is not passively waiting for the confirmation of the Alliance commitments (Art. 5 of the Treaty) but is taking actual actions to strengthen its own potential. It concerns both its budget expenditure (2\% of its GDP is spent on armament) and material and personal support for armed forces, including, among others, the creation of its Territorial Defence Force branch. It is necessary for Poland to provide information concerning the reasons for taking these actions, i.e. their stemming from an active defence policy. This would make it easier for it to defy allegations, also external ones (Russia), as to their confrontational nature. It is imperative that this stance be clearly communicated and negotiated within Central Europe (i.a. the Visegrád Group), (Gizicki, 2013). A concern for the state's own security 
does not need to signify acting against other subjects of international relationships. And yet, Sun Tzu's adage still seems relevant in this respect: "a gentleman keeps his sword by his side."

\section{Coherence, cooperation and enlargement of NATO}

NATO should constantly confirm its coherence and close cooperation among its member states in the area of security and defence of all of its allied territory (Friss, 2017; Giegerich, 2016). It is essential that it be done with support from its closes neighbourhood which is or may become a target for other aggressive subjects, including Russia. Taking into consideration the challenges and extent of threat, second-class membership is out of question as are different levels of cooperation, division as to the priorities and lines of action. Security is indivisible, and this also pertains to allied cooperation and priorities-setting within international organisations (Kammel, Zyla, 2018). An additional challenge in this area is to undertake some actions aimed at a closer cooperation and - in the long-term - an enlargement of NATO to include new states from this region. In 2008, during the Bucharest summit, a discussion on Georgian and Ukrainian membership was initiated (Herzog, 2010). However, due to the war in Ukraine, its internal problems, particularly in economic and defence areas, as well as its political volatility, the issue of its membership in NATO needs to be postponed. The situation is very different when it comes to the prospective Georgian membership in NATO. The Alliance's admission that it is interested in this state joining NATO, voiced in 2012 (Chicago), in 2014 (Newport) and later, necessitates consistent sustenance. Especially that Georgian internal situation could evolve in the direction of strengthening its cooperation with Russia. Thus the need to make Georgia's way to membership more realistic, if only by means of defining boundary conditions for this state - MAP (Membership Action Plan). Such a Plan was also devised for Serbia. In the case of the former state there is an actual chance of attaining the desired result. When it comes to Serbia, on the other hand, the situation is much more complex, particularly due to its close relationship with Russia. However, regardless of the difficulties presenting themselves in the process, the Warsaw summit imposed on NATO an obligation to launch concrete discussions and take decisions concerning the actual perspectives as regards those states. This will inevitably affect credibility and reliability of the declarations which need to evolve in the direction of final, potentially difficult, decisions. Thanks to successful negotiations between Macedonia and Greece, North Macedonia will probably gain NATO membership already in 2019 .

\section{NATO SUMMIT IN CARDIFF 2014 - POLITICAL INDECISION}

The year 2014 brought about a radical change in the manner in which NATO must approach its future tasks. Collective defence of the territory of its member states, strengthening of their defensive capacity, solidarity and coherence are vital for an effective cooperation and are encoded in the Alliance's day-to-day operation. It seems, 
however, that the period preceding the Newport summit was characterised by a drop in this activity and a relative weakening of vigilance on the part of NATO. Its approach to the issue of selecting a venue for the NATO 2014 Summit corroborates this hypothesis. None of the member states was particularly willing to undertake this task. The decision to meet in Wales was made a year prior to the summit. The lack of willingness to hold the most important NATO meeting, wrapping up its previous operation and setting out an agenda for the current activity, cannot be perceived to be a source of pride for the Alliance. The Newport Summit was held on September 4th and 5th, 2014. During the five months preceding the Summit a hybrid war had been fought in Ukraine, a country directly bordering with a few of NATO member states. A war in which Russia's participation was extensive, even though hidden. Despite all of that, the decisions taken during the summit did not meet any of the needs and expectations, nor did they reflect the ongoing combat in close proximity of NATO territory (Broke-Holland, 2014; Koziej, Pietrzak, 2014; Fryc, 2016).

The postulated operational activities were in fact infinitesimal. Admittedly, the decision was made to found a contingent which could be immediately deployed to the threatened states' territory. Russian aggression on the territory of Ukraine was, as expected, condemned. Trade cooperation between the U.S. and Russia was suspended. The Readiness Action Plan (RAP) was launched and it outlines the possibility of launching several actions in case borders or territory of the Alliance member states are threatened. The command of the Multinational Corps Northeast based in Szczecin was strengthened. This allowed to upgrade its combat readiness rating to High Readiness Forces. Moreover, six commands were confirmed to be operational, which entails their being ready to deploy corps of 60,000 soldiers to a threatened territory within 10 days. NATO also decided to intensify its activity as regards regular military training of its armed forces. An instance of this activity could be the regular military manoeuvres of NATO armed forces taking place in Poland and referred to by the name "Anaconda."

Decisions taken during the Summit concerned Ukraine as well (Wolff, 215). They were the opposite of rather symbolic involvement on the part of the EU. NATO gave support to Ukraine's armed forces as regards a few programmes aimed at strengthening their defence capacity, including the financial aspect. The discussion on and decisions aimed at the strengthening of the Treaty commitments concerning the member states' spending of a percentage of GDP on armament proved to be of major importance. It was agreed upon that each state should reach the required level of $2 \%$ of GDP spent on armament within the following 10 years. Decisions arrived at during this Summit concerned also some areas outside the Treaty territory. In this respect, they primarily concerned NATO support for stabilisation processes in Afghanistan and Iraq.

The key failure of the Newport Summit was the lack of any decision concerning the distribution of NATO armed forces on the so-called Eastern Flank. This, undoubtedly, was not without its consequences for the further escalation of actions undertaken by Russia and Ukrainian separatists as well as for the numerous provocations on the part of Russia aimed against NATO and its particular member states in the closest proximity to Ukraine (Deni, 2014; Lasconjarias, 2014). 


\section{NATO SUMMIT IN WARSAW 2016 - POLITICAL DETERMINATION}

The Warsaw NATO Summit was held in July 2016. The choice of the capital of Poland for the venue was not accidental. The Alliance's leaders aimed to emphasise, also in this way, their determination to reinforce the actions undertaken by NATO in the East (Flockhart, 2015; Glatz, Zapfe, 2016). Russia did not even pretend to abandon the implementation of its interests in the so-called close neighbourhood. Barack Obama's concept of resetting relations with Russia, postulated from the dawn of his presidency, proved ineffective. Unfortunately, Obama understood that quite late, only in 2014 when Eastern Ukraine was already essentially lost. Therefore, NATO came to realise that it was necessary to build up its actions. Central Europe had, understandably, high hopes for the Warsaw Summit. These came in the shape of justified plans and expectations (Belkin, 2016). The decisions reached in Warsaw were satisfactory for Central Europe. All member states' leaders were convinced of the necessity of taking more extensive and more confident decisions and practical actions.

The most important of these decisions, compensating in a way for the lack of courage back in Newport, was the formation of four international battlegroups at battalion level. They are present on the so-called Eastern Flank on a constant rotational basis. Moreover, the deployment in Poland of the U.S. Army armoured brigade is also of vital importance. It is certainly a relevant component of deterrence activities, allowing at the same time to strengthen supportive cooperation. It has a great significance not only for Poland but also for the whole region (Larsen, 2016; Lesser, 2016; Mattelaer, 2016).

Another important and desirable decision was to strengthen cooperation and bilateral coordination of undertakings between NATO and the EU at the level of prevention of asymmetrical and hybrid threats but also of migration crises. This has resulted in a shift of attitude toward these issues in many EU member states. Of key importance is aid for refugees in need which is to be delivered to countries of their origin or to other safe countries situated as close as possible to their domiciles. Moreover, as a part of implementation of this commitment actions preventing illegal migrations were launched in the Mediterranean Sea (Sea Guardian Operation). With respect to the process of eliminating hybrid threats, attention has been drawn to the scale and scope of destructive activities brought about by disinformation and propaganda, especially Russian. Constant monitoring of those activities and joint support to counteract them are a key component in fighting off threats in information warfare.

Cyberspace has become one of the crucial battlefields for hybrid activities. Therefore, Warsaw Summit discussions were to a great extent devoted to this problem. Increasing the intensity of cooperation in this area among NATO member states, skill and information sharing as well as elimination of attacks on ICT networks constitute one of the most urgent challenges.

Since the very idea of missile defence (Missile Defence Capability) had already been implemented, during the Summit in Warsaw, NATO member states decided to reinforce these activities. The completion of the common missile shield project is still one of the major challenges but one can already notice considerable progress in this respect. The decisions reached on the topic of implementing this system during the 
Lisbon Summit in 2010 are becoming quantifiable. Initial combat readiness has already been achieved and reaching full effectiveness seems to be just a matter of time, despite not infrequent disagreements as to the details.

One of the major concerns, for obvious reasons, during the Warsaw Summit was the situation in Ukraine. Poland is the first state to have officially recognised the sovereignty of Ukraine, back in 1991. What is more, support for this state is for Poland one of the components of its raison d'état. Thus, support for the sovereignty and territorial integrity of Ukraine was emphasised once again in Warsaw. Additionally, financial aid for Ukraine has been substantially augmented, i.a. by means of starting eight new NATO funds. They encompass i.a. help in securing cyberspace, logistical and medical support which facilitates accessing rehabilitation for wounded soldiers of Ukrainian Army.

One of the vital topics of the discussion and the following decisions was the intensification of the fight against terrorism, especially the terrorism spread by ISIS in the Near East. One of the consequences of this decision was, among others, to extend the mission in Afghanistan (Resolute Support) and to launch annual financial support for the state's government amounting to $\$ 5$ billion. Additionally, the previous commitments on training support for the army in Iraq and reinforcement support for the forces cooperating with NATO in Jordan, Tunisia and Libya were upheld. The direct fight against ISIS in Syria and its proximity was intensified by the decision to give the coalition forces fighting ISIS access to the Airborne Early Warning and Control System (AWACS). Thanks to that it was possible to fight off threats on the NATO territory in the region (particularly in Turkey) but also in Syria and Iraq with greater effectiveness (Upadhyay, 2016).

The Warsaw Summit also proved to be important for Central Europe as regards NATO decisions in the area of energy security. It was determined that a diversification of suppliers, continued search for new markets of petroleum extraction and the dangers related to NATO member states being dependent on Russia's raw materials exports are all of crucial importance. It was unequivocally concluded that there is an urgent need to strengthen activities enabling NATO to put an end to this unfavourable situation in an expeditious manner. One has to emphasise the need to obstruct Russian monopoly related to, among others, its plans of building the Nord Stream 2 with higher effectiveness. Numerous political entities have realised that the project in question cannot be viewed in economic terms exclusively. It is fundamentally a political enterprise which may serve - in a crisis situation - as a tool to exert influence on Central European states which have been ignored, omitted in this project. Moreover, the privileged position given to Russia when it comes to economic cooperation, taking into consideration Russia's confrontational activities in numerous areas, does not contribute to building trust among NATO member states.

\section{NATO SUMMIT IN BRUSSELS 2018 - POLITICAL COHERENCE}

The official NATO Summit planned for 2018 was preceded by a meeting of NATO member states' leaders held in May 2017 in Brussels where the key issues in the area of both challenges and threats facing the organisation were discussed. The 2017 meeting 
could be thus seen as a prelude of sorts and a preparation of the agenda for the official Summit in 2018.

The Brussels NATO Summit was held in July 2018 in the shadow of quite unpredictable actions and destructive activity on the part of many subjects.

Firstly, there was the ongoing war in Eastern Ukraine. Russia was constantly undertaking activities aimed at advancing its interests in the region. It was clear that President Vladimir Putin was striving to gain a superpower status for Russia. And it was difficult not to get the impression that it was all happening in direct opposition to NATO. Russia's war doctrine of 2014 still points to NATO as to its main opponent. Moreover, the following months witnessed new developments which clearly demonstrated an increase in this state's negative military activity. One could observe the culmination of this activity for instance when Russian Navy launched an attack on Ukrainian units in the Kerch Strait in November 2018. There is no doubt that Russia is testing the West as to its reaction to further its prospective territorial annexation. Therefore, there is no question that increased involvement of NATO in Central and Eastern Europe is indispensable.

During the Brussels Summit, the U.S. President's, Donald Trump, viewpoint on the matter was well heard. His stance on the issues of security and the U.S. involvement in global politics is quite original and consistent. President Trump unequivocally specified the U.S. security priorities pertaining to the defence of American interests. The Alliance commitments, including those within NATO, are not threatened. He firmly emphasised, however, that the U.S. are not interested in being the only state involved in maintaining the global stability at their own expense with no support on the part of the remaining NATO member states. He was referring to the guarantee of spending $2 \%$ of a state's GDP on armament. Apart from a few exceptions (the U.S., Great Britain, Greece, Estonia, Latvia, Poland, Lithuania and Romania), the Alliance member states are clearly behind with their implementation of this commitment. Trump does not even take into consideration such a possibility and he is open and very clear on this point (the famous stop "the World's piggy bank").

In accordance with the U.S. standpoint one of the vital issues for NATO is its defensive and deterring capabilities policy, including nuclear consensus policy (Durkalec, 2018; Bell, 2018; Suer, 2016). The idea of strengthen its defensive and deterring capabilities is based on NATO $4 \times 30$ initiative (NATO Readiness Initiative). It is related to the necessity of maintaining a constant combat readiness, based - till 2020 - on 30 motor battalions, 30 air force squadrons, 30 warships. For each of these formations the attainment of combat readiness within up to 30 days is of key importance. The Brussels Summit also took up the matter of the creation of a logistical command in Germany, Joint Support and Enabling Command (JSEC), and the re-creation of Atlantic joint force command in Norfolk. This is an opportunity to improve the effectiveness of the U.S.-Europe management of the Alliance armed forces (Howorth, 2017).

The intensification of actions in the area of fighting off terrorism is also of considerable significance for the security of NATO member states. It was decided once again in Brussels to support stabilisation processes in Iraq and Afghanistan. This is a relevant step in view of the need to eradicate the pro-terrorist moods still present in these countries. Another necessary step is to reinforce the support for the Near East 
states (e.g. Tunisia and Jordan) whose actions are advantageous to NATO counter terrorism campaign. NATO's Southern Flank requires support due to the migration paths which have been in use for the last couple of years and which may also be conducive to terrorists' agendas.

From the perspective of Central Europe, NATO decision to invite Macedonia, which since 2019 has been known as North Macedonia, to accession talks was also a significant event. It will allow Greece to accept the fact that this state is to enter the Alliance. This in turn will allow yet another NATO member state to strengthen the region's position within such programmes as, among others, the Three Seas Initiative.

Undoubtedly, the greatest importance should be accorded to the fact that the Brussels Summit confirmed the permanent NATO military presence on the so-called Eastern Flank. Allied solidarity has a crucial value, especially for states such as Estonia, Lithuania, Latvia, Poland which are direct neighbours of volatile and confrontational Russia. The presence of the battalion battlegroups is a necessity stemming from the actual politics shaping the region.

$$
* * *
$$

Each year of the 21st century brings along new and important challenges for international security. Many of them can be effectively minimalised or completely eliminated. Many, however, cannot, and they continue to present considerable problems for years, captivating significant diplomatic and military resources.

The analysis undertaken in the present paper allows me to formulate a few general conclusions. These stem from the assumptions made in the introductory part of the text.

Firstly, the decisions reached during the summits in Newport, Warsaw and Brussels corroborate the thesis concerning the effectiveness of the actions taken by Central European states, including Poland. A great determination and involvement on the part of their authorities and diplomacy could be observed both during the proceedings and in decision-making process. States of the region have clearly expressed their interests, and they support, directly and considerably, all security processes undertaken by the organisation. NATO is strong with the strength of its member states, including thirteen states of the region. The importance, position and presence of NATO on the so-called Eastern Flank increased substantially in 2018. This is a vital element of the community of interests and of ensuring security in this part of Europe.

Secondly, it is difficult to question the fact that at present there is no alternative to NATO. The organisation has played a crucial role in shaping international security not only within the Treaty territory. The Alliance's actions have been visible and effective not only within the transatlantic setting. Many of them exceed the area. It allows NATO to protect, in an effective manner, security interests not only of its member states or allies from outside the organisation, but also of civilians living in the countries affected by crises or wars. It is, however, clear that NATO should react faster and in a more effective way in response to the dynamically changing global reality. A good illustration of this are, for instance, wars in Ukraine or Syria. On multiple occasions one could observe a lack of unanimity and decisiveness on the part of NATO in such circumstances. 
Finally, the successive NATO summits provide an opportunity not only to discuss vital problems that the organisation is facing but also to arrive at clear, necessary and desirable decisions which exert actual influence on international security. Some of them may be coming late or be too precautionary. Yet still, despite that, NATO proves to be capable of effectively organising security area with multiple subjects. On analysing the circumstances surrounding the summits in Wales, Poland and Belgium as well as the decisions reached there, one can notice that NATO clearly evolved, "matured" to take considerably more active decisions, especially as concerns its increased presence on the eastern border. The reality of provocations and threats on the part of Russia had been confirmed. Therefore, in as few as two-three years NATO went from releasing formulations phrased in a very general way (Newport) to issuing actual decisions (Warsaw and Brussels).

\section{REFERENCES}

Belkin P. (2016), NATO's Warsaw Summit: In Brief, Washington.

Bell R. (2018), The Challenges of NATO Nuclear Policy, FIIA Working Paper, October.

Blum J., Potrafke N. (2019), Does a Change of Government Influence Compliance with International Agreements? Empirical Evidence for the NATO Two Percent Target, Defence and Peace Economics.

Broke-Holland L., Mills C. (2014), NATO Wales Summit 2014: Outcomes, London.

Deni J. R. (2014), NATO's New Trajectories after the Wales Summit, Parameters, No. 44.

Durkalec J. (2018), The 2018 U.S. Nuclear Posture Review, NATO's Brussels Summit and Beyond, Livermore.

Flockhart T. (2015), Preparing for NATO's Warsaw Summit. The Challenges of Adapting to Strategic Change, Copenhagen.

Franke U. (2018), Roundtable Feature: Now What? Lessons for Europe from the NATO Summit, “Texas National Security Review”, Vol. 1, Issue 4, pp. 137-139.

Friis K. (2017), NATO and the Collective Defence in the 21th Century. An Assessment of the Warsaw Summit, London.

Fryc M. (2016), From Wales to Warsaw and Beyond: NATO's Strategic Adaptation to the Russian Resurgence on Europe's Eastern Flank, "Connetions: The Quortelly Journal”, No. 4, pp. 45-65.

Giegerich B. (2016), NATO's Strategic Adaptation, the Warsaw Summit and Beyond, "The Polish Quarterly of International Affairs", Issue 1, pp. 61-68.

Gizicki W. (2013), A Security Community. Poland and Her Visegrad Allies: the Czech Republic, Hungary and Slovakia, Lublin.

Glatz R. L., Zapfe M. (2016), NATO Defence Planning between Wales and Warsaw, Berlin.

Herzog S. (2010), Western Values and Strategic Interest? Evaluating Potential Georgian Membership in NATO, "Central European Journal of International and Security Studies", Vol. 4, No. 1, pp. 123-139.

Howorth J. (2017), EU-NATO cooperation: the key to Europe's security future, "European Security", Vol. 26, Issue 3, pp. 454-459. 
Ivančík R., Nečas P. (2017), Towards Enhanced Security: Defense Expenditures in the Member States of the European Union, "Journal of Security and Sustainability Issues", Vol. 6, No. 3, pp. 373-382.

Kammel A. H., Zyla B. (eds.) (2018), Peacebuilding at Home. NATO and its 'New' Member States after Crimea, Baden-Baden.

Keil S., Oliver T. (2016), What Would a US Policy of "restraint" mean of the Warsaw NATO Summit, "International Politics Reviews", Vol. 4, Issue 1, pp. 31-35.

Koziej S., Pietrzak P. (2014), NATO Summit in Newport, "Bezieczeństwo Narodowe”, No. 31, pp. 11-29.

Křǐž Z., Fridrichová K. (2015), Libya and Criteria for Humanitarian Intervention, “Czech Journal of Political Science", No. 3, pp. 183-199.

Larsen J. A. (2016), Time to Face Reality: Priorities for NATO's 2016 Warsaw Summit, Research Paper, NATO Defence College, No. 126.

Lasconjarias G. (2014), NATO's Posture after the Wales Summit, IAI Working Papers, No. 14.

Lesser I. (2016), The NATO Warsaw Summit: Reflections on Unfinished Business, The International Spectator, "Italian Journal of International Relations", Vol. 51, Issue 4, pp. 131-133.

Mattelaer A. (2016), The NATO Warsaw Summit: How to Strengthen Alliance Cohesion, "Strategic Forum", No. 296.

Nünlist Ch., Zapfe M. (2014), NATO after Wales: Dealing with Russia - Next Steps, Zürich.

Smith M. A., Timmins G. (eds.) (2018), Building a Bigger Europe: EU and NATO Enlargement in Comparative Perspective, London.

Suer T. (2016), Just Leave It: NATO's Nuclear Weapons Policy at the Warsaw Summit, "Arms Control Today", Vol. 45, No. 5, pp. 16-21.

Sydoruk T., Tyshchenko D. (2018), Central Europe on Russia-Ukraine Conflict. Positions and Responses, "Central European Journal of International and Security Studies", Vol. 12, Issue 3, pp. 81-105.

Terlikowski M. (2018) Newport - Warsaw - Brussels: NATO in Defence of Peace in Europe, Warsaw.

Upadhyay D. K. (2016), NATO Warsaw Summit: Outcomes and Implications, ISSUE Brief, 2 August.

Wolff A. T. (2015), The future of NATO enlargement after the Ukraine crisis, "International Affairs", Vol. 91, Issue 5, pp. 1103-1121.

\begin{abstract}
The collapse of the Cold-War order in Europe brought about a radical change in the global security system. The dissolution of the Soviet Union and the disbandment of the Warsaw Pact created a situation where the only serious and effective guarantee of stability in Europe was NATO. Central European states, which until that time had been subordinated to the USSR, unequivocally and consistently chose to pursue the Euro-Atlantic direction in their security policy. The decision resulted in their gaining full, even though gradual, membership in the Alliance during the years 1999-2004. The accession process was first completed by the Czech Republic, Hungary and Poland. Central Europe is not free from dangers stemming from national and supranational transformations. NATO is facing the need to increase its activity and systematically ensure joint cooperation and security guarantees as regards all its member states. This is primarily caused by a revival of Russia's superpower ambitions under the presidency of Vladimir
\end{abstract}


Putin and an escalation of terrorism and cyberspace threats. The decisions and practical actions related to biennial NATO summits are of vital importance in this respect. The text presented here is an analysis of the security of Central Europe within NATO structures in the light of the last three NATO summits: in Newport in 2014, in Warsaw in 2016 and in Brussels in 2018.

Keywords: NATO, NATO Summit, Central Europe, transatlantic security

\section{EUROPA ŚRODKOWA W RAMACH TRANSFORMACJI NATO 2014-2018}

\section{STRESZCZENIE}

Upadek porządku zimnowojennego w Europie spowodował radykalną zmianę w globalnym systemie bezpieczeństwa. Rozpad Związku Radzieckiego i likwidacja Układu Warszawskiego doprowadziły do sytuacji, w której jedynym poważnym i efektywnym gwarantem stabilności Europy stało się NATO. Państwa Europy Środkowej, które dotąd podporządkowane były ZSRR jednoznacznie i konsekwentnie wybrały euroatlantycki kierunek w polityce bezpieczeństwa. Efektem tego stało się ich pełne, choć stopniowe członkostwo w Sojuszu w latach 1999-2004. Pionierami w tym względzie były Czechy, Węgry i Polska. Europa Środkowa nie jest wolna od zagrożeń związanych z przemianami na poziomie narodowym lub ponadnarodowym. Odrodzenie się mocarstwowych ambicji w Rosji rządzonej przez Władimira Putnia, eskalacja zagrożeń terrorystycznych bądź zagrożenia w cyberprzestrzeni wymagają od NATO większej aktywności i systematycznego potwierdzania solidarnej współpracy i gwarancji bezpieczeństwa wobec wszystkich członków. Kluczowe znaczenie w tym względzie mają decyzje i praktyczne działania związane z cyklicznymi Szczytami NATO. Prezentowany tekst podejmuje analizę bezpieczeństwa Europy Środkowej w ramach NATO w świetle trzech ostatnich szczytów: 2014 w Newport, 2016 w Warszawie i 2018 w Brukseli.

Słowa kluczowe: NATO, szczyt NATO, Europa Środkowa, bezpieczeństwo euroatlantyckie 
